\title{
PENTINGNYA KELAS KEWIRAUSAHAAN \\ PADA SMK PARIWISATA
}

\author{
Badraningsih Lastariwati \\ Teknik Boga FT UNY \\ badraningsih@uny.ac.id
}

\begin{abstract}
Abstrak: Peningnya Kelas Kewirausahaan pada SMK Pariwisata. Kajian ini dimaksudkan untuk menentukan peran kelas kewirausahaan dalam menanamkan jiwa kewirausahaan, nilai, dan pengalaman siswa SMK Tata Boga dalam menyiapkan lulusan yang memiliki jiwa mandiri yang saat ini menjadi tantangan dalam pendidikan, yaitu antara lain: meningkatnya jumlah dan kualitas pendidikan kejuruan untuk memenuhi kebutuhan global dan lokal, dan menghasilkan tenaga kerja yang kreatif. Tujuan yang menarik adalah 70\% lulusan SMK dapat bekerja setiap tahun. Hal ini memerlukan perlakuan. fasilitas, dukungan, dan upaya-upaya untuk mencapai kewirausahaan untuk mencapai kualitas lulusan sekolah kejuruan sesuai dengan kebutuhan dunia kerja. Progrm ini harus didisain berdasarkan kurikulum yang didisain dan dikembangkan kebutuhan stakeholders. Kelas kewirausahaan menerapkan kurikulum terintegrasi ke dalam mata pelajaran produktif. Dalam kelas kewirausahaan diharapkan dapat lebih efektif dalam menumbuhkan jiwa kewirausahaan dan kemandirian sehingga lulusan akan lebih memiliki jiwa yang bebas di dalam setiap situasi.
\end{abstract}

Keywords : kewirausahaan, kelas kewirausahaan entrepreneurship class, wisata kuliner smk.

\section{THE ROLES OF ENTERPRENEURSHIP CLASS FOR VOCATIONAL HIGH SCHOOL OF TOURISM.}

\begin{abstract}
The Role of Entrepreneurship Class for Vocational High School of Tourism. This study aimed to determine the role of the entrepreneurial class in cultivating the entrepreneurial spirit, values and skills of SMK culinary student, to prepare graduates who have the spirit of independence as a responde to the current challenges including quantity and quality of vocational education to meet local, national, and global needs. The interesting objective is that about 70\% of graduates shold be employed. In addition SMK generally provides entrepreneurship training in services. It need treatment, facilitatation, and encouragement of learners in order to become independence, responsible, creative, innovative, sporty, and entrepreneurship efforts to achieve the quality of vocational education graduates that meet the need of work place. Entrepreneurial class implements integrated subjects of vocational entrepreneurship. The entrepreneurial class is expected to be more effective in growing entrepreneurship spirit and independence of the prospective graduates of culinary tourism program.
\end{abstract}

Keywords: entrepreneurship, entrepreneurship class, SMK culinary tourism

\section{PENDAHULUAN}

Pemerataan akses dan peningkatan mutu pendidikan akan membuat warga Indonesia memilki kecakapan hidup (life skills) sehngga mendorong tegaknya pembangunan manusia seutuhnya serta masyarakat madani dan modern yang dijiwai nilai-nilai Pancasila, sebagaimana yang diamanatkan dalam UU No. 20 Tahun 2003 tentang Sistem Pendidikan Nasional [Renstra Kementrian Pendidikan Nasional (RPJMN),2010-2014].RPJMNtahun ２010-2014 ditujukan untuk lebih memantapkan pembangunan Indonesia disegala bidang dengan menekankan upaya peningkatan kualitas sumberdaya manusia (SDM) termasuk kemampuan ilmu dan teknologi serta panguatan 
daya saing perekonomian.Tantangan yang ada pada saat ini yang berhubungan dengan pendidikan antara lain meningkatkan kuantitas dan kualitas pendidikan kejuruan (vokasi) untuk memenuhi kebutuhan lokal dan nasional serta mampu bersaing secara global, serta menghasilkan SDM kreatif melalui pendidikan yang diperlukan dalam pengembangan ekonomi kreatif.

Untuk mencapai hal tersebut dalam sasaran strategis untuk mencapai tujuan strategis $T_{3}$ (2010-2014) yang secara keseluruhan terdapat 11 sasaran,maka ada dua target yang menarik yang menjadi tujuan yaitu sekitar $70 \%$ lulusan SMKbekerja pada tahun kelulusan dan seluruh SMK menyediakan layanan pembinaan pengembangan kewirausahaan.Sejalan dengan Renstra Kementrian Pendidikan Nasional, maka dalam Road Map Pengembangan SMK 20102014 tentang Visi Direktorat Pembinaan SMK diharapkan terwujudnya SMK yang dapat menghasilkan tamatan berjiwa wirausaha (entrepreneur) yang siap kerja, cerdas, kompetitif, dan memiliki jati diri bangsa, serta mampu mengembangkan keunggulan lokal dan dapat bersaing dipasar global.

Pembelajaran merupakan suatu proses yang berlangsung seumur hidup, yaitu pembelajaran sejak lahir hingga akhir hayat yang diselenggarakan secara terbuka dan multi makna.Pembelajaran seumur hidup berlangsung secara terbuka melalui jalur :formal,non formal, serta informal yang dapat diakses oleh peserta didik setiap saat tanpa dibatasi usia,tempat, dan waktu. Terkait dengan pendidikan multi makna diselenggarakan dengan berori-entasi pada pembudayaan,pemberdayaan, pembentukan akhlak mulia, budi pekerti luhur dan watak kepribadian, atau karakter yang unggul serta berbagai kecakapan hidup(life skills).Paradigma ini memperlakukan,memfasilitasi, dan mendorong peserta didik menjadi subyek Pembelajar mandiri yang bertanggung jawab,kreatif, inovatif, sportif, dan berkewirausahaan(Renstra 2010-2014).

Salah satu kondisi pembelajaran yang dapat mendukung pencapaian kompetensi ada-lah mengembangkan proses pembelajaran berbasis aktivitas siswa dengan latar kegiatan dunia kerja. Pembelajaran yang perlu dikembangkan dalam rangka pembentukan kompe-tensi adalah interaksi yang memungkinkan para siswa mampu membangun penge-tahuan, sikap, dan keterampilannya melalui berbagai modus transformasi pengala-man belajar. Oleh karena itu, pengembangan kurikulum program studi pendidikan kejuruan perlu berorientasi pada dunia kerja, sedangkan pembelajarannya berorientasi pada siswa atau belajar mahasiswa aktif. (Depdiknas, 2004)

Upaya untuk mencapai kualitas lulusan pendidikan kejuruan yang sesuai dengan tuntutan dunia kerja tersebut, perlu didasari dengan kurikulum yang di-rancang dan dikembangkan dengan prinsip kesesuaian dengan kebutuhan stakeholders.Kurikulum yang merupakan salah satu kelengkapan dalam penyelenggaraan pendidikan memegang peran penting dalam menentukan arah dan tujuan pendidikan.Kurikulum pendidikan kejuruan secara spesifik memiliki karakter yang mengarah kepada pembentukan kecakapan lulusan yang berkaitan dengan pelaksanaan tugas pekerjaan tertentu.Hal ini disebabkan karena perkembangan teknologi di industri terjadi sangat cepat, sementara hal yang sebaliknya terjadi pada dunia 
pendidikan.Untuk itulah mitra industri sangat diperlukan sebagai wahana pengenalan terhadap dunia kerja, standar kerja, dan perkembangan teknologi mutakhir. Jaringan kerja dengan industri atau dunia kerja perlu dikembangkan untuk membantu kelancaran dan keuntungan akademik yang optimum.

Bagaimanapun sumberdaya manusia merupakan modal yang sangat penting untuk pembangunan bangsa dan meningkatkan daya saing bangsa dan untuk mencetak sumberdaya manusia yang handal diperlukan lembaga pendidikan yang mempunyai kurikulum yang mampu menghasilkan lulusan yang bisa diterima oleh dunia usaha dan dunia industri. Dampak kebijakan pemerintah dengan adanya perkembangan rasio SMK:SMA = 70:30, akan mening-katkan persaingan pasar kerja di Industri semakain ketat. Tingkat Partisipasi Angkatan Kerja (TPAK), mengindikasikan besarnya penduduk usia kerja yang aktif secara ekonomi di suatu negara atau wilayah. TPAK diukur sebagai persentase jumlah angkatan kerja terhadap jumlah penduduk usia kerja. Indikator ini menunjukkan besaran relatif dari pasokan tenaga kerja (labour supply) yang tersedia untuk memproduksi barang-barang dan jasa dalam suatu perekonomian. Sejak Februari 2008 hingga Februari 2009 TPAK mengalami peningkatan sebesar $0,2 \%$, yaitu dari $67,33 \%$ menjadi $67,60 \%$ (BPS, 2009). Pertumbuhan tenaga kerja yang kurang diimbangi dengan pertumbuhan lapangan kerja akan menyebabkan tingkat kesempatan kerja cenderung menurun.Persoalan mendasar ketena-gakerjaan di Indonesia saat ini adalah meningkatnya tingkat pengangguran. Ini disebabkan pertambahan angkatan kerja baru lebih besar dibanding pertumbuhan lapangan kerja produktif yang dapat diciptakan setiap tahun.

Agar daya serap lulusan dari sejumlah SMK tinggi maka salah satu usaha pemerintah yang perlu dilakukan adalah adanya kebijakan regulasi pembentukan SMK menurut sector lapangan usaha dan profil ketenagakerjaan pada tingkat lokal, nasional, serta internasional yang akan sangat berguna untuk merencanakan kebutuhan SMK di masa yang akan mendatang. Secara tidak langsung, hal ini merupakan cara SMK untuk menyediakan tenaga kerja sesuai dengan kebutuhan DU/DI yang relevan dengan sumber daya masing-masing daerah. Kebutuhan program pendidikan SMK ditentukan oleh adanya kebutuhan akan kualifikasi jaba-tan dan keterampilan tenaga kerja yang sangat diperlukan guna mengembangkan berbagai sector perekonomian bangsa.

Program kewirausahaan di SMK pada dasarnya merupakan salah satu program pembelajaran yang bertujuan untuk penanaman nilai kewirausahaan melalui pem-biasaan, penanaman sikap, dan pemeliharaan perilaku wirausaha.Kewirausa-haan pada hakikatnya adalah sifat,ciri, dan watak seseorang yang memiliki kemauan dalam mewujudkan gagasan inovatif kedalam dunia nyata secara kreatif. Inti dari kewirausahaan adalah kemampuan untuk menciptakan sesuatu yang baru dan berbeda (kreatif dan inovatif). Kreativitas adalah berpikir sesuatu yang baru,inovasi adalah bertindak melakukan sesuatu yang baru. Secara efistimologis kewirausahaan(entrepreneurship) pada hakikatnya merupakan suatu kemampuan dalam berpikir kreatif dan berperilaku inovatif yang dijadikan dasar,sumber daya, tenaga 
penggerak, tujuan, siasat, dan kiat dalam menghadapi tantangan hidup (Suryana, 2003).

Wirausaha (entrepreneur) adalah seseorang yang mempunyai daya kreativitas dan daya inovasi yang kuat, memiliki kemampuan manajerial yang tinggi, menguasai pengetahuantentang bisnis secara mendalam,sertaberperilaku dengan tujuan membentuk suatu usaha baru.Dengan menguasai jiwa entrepreneur diharapkan memiliki kombinasi motivasi, visi, optimisme, komunikasi, dan dorongan untuk memanfaatkan suatu peluang usaha.

Kelas kewirausahaan yang menerapkan pengintegrasian mata pelajaran kewirausaha-an pada setiap muatan produktif diharapkan menekankan penanaman jiwa wirausaha. Dengan dimilikinya jiwa wirausaha maka institusi maupun individu akan memiliki rasa optimis untuk menciptaan cara-cara baru yang lebih efektif, efisien dan praktis. Pembelajaran kewirausahaan merupakan salah satu penunjang mata diklat teori. Kewirausahaan di SMK saat ini implement-tasinya hanya sekitar 1,93\% dari seluruh jam pelajaran di SMK selama enam semester.Hal ini belum memungkinkan terbentuknya kemandiriaan dan belum dapat sepenuhnya mena-namkan jiwa wirausaha bagi lulusan SMK oleh sebab itu desain pembelajaran kewirausahaan di SMK perlu dikaji ulang mulai dari : kurikulum, strategi pembelajaran, metode, media, dan cara guru yang mengampu kewirausahaan (Sarbiran,2002)

SMK kelompok pariwisata merupakan salah satu program keahlian yang ada pada kelompok Keahlian Pariwisata Seni dan Kerajinan pada SMK yang ada di Indonesia.Pada Program Tata Boga ini memiliki kompetensi utama Jasa Boga dan Patiseri, dimana program ini juga untuk menunjang program Restoran dan Perhotelan yang ada di SMK Pariwisata.Berda-sarkan uraian terdahulu maka pengembangan kelas kewirausahaaan sangat penting karena kelas kewirausahaan merupakan wahana paling tepat untuk menyiapkan lulusan yang kompe-ten dibidangnya, yang diharapkan dapat ikut bersaing di pasar kerja atau dapat menciptakan lapangan kerja sendiri melalui usaha kreatif yang didirikan sehingga kesejahteraan masyarakat dapat terpenuhi

Pada kelas kewirausahaan ini diharapkan lebih efektif dal am penanaman jiwa wirausaha dan penanaman kemandirian SMK Pariwisata Tata Boga, sehingga para siswa nantinya lebih mandiri/professional dalam segala situasi berusaha.Karena dengan adanya penataan kurikulum kewirausahaan yang ter integrasi pada pembelajaran produktif yang ada, diharapkan dengan kelas kewirausahaan ini,penanaman jiwa,nilai dan perilaku kewirausahaan menjadi lebih efektif dan efisien

\section{Penyelenggaraan pendidikan di sekolah menengah kejuruan}

SMK merupakan bagian integral dari sector ekonomi yang ikut mendorong pertumbuhan ekonomi nasional, sehingga perlu dikembangkan kuantitas dan kualitasnya. Kualitas SMKakan mereflesikan kualitas tenga kerja Indonesia yang perlu dibangun untuk meningkatkan keunggulan kompetitif sumber daya manusia Indonesia. Dengan demikian, SMK memegang peran penting dalam menekan angka pengangguran di Indonesia.Untuk itu, perlu diaktualisasikan didik untuk dapat bekerja dalam bidang tertentu. Lebih jauh dijelaskan dalam Peraturan Pemerintah nomor 19 tahun 2005 tentang Standar Nasional 
Pendidikan (SNP), tujuan penyelenggaraan SMK adalah pendidikan menengah kejuran mengutamakan penyiapan siswa untuk memasuki lapangan kerja serta sikap professional.

Pendidikan kejuriuan harus berorientasi ekonomis dan produktif.Orientasi ini diharapkan menghasilkan entrepreneur muda yang andal.Selain memiliki jiwa entrepreneur siswa SMK diharapkan mengikuti perkembangan teknologi, menguasainya, serta menerapkannya. The American Vocational Assocation menyatakan bahwa pendidikan kejuruan pada dasarnya direncanakan untuk mengembangkan keterampilan, kemampuan pemahaman, sikap, kebiasaan kerja, dan pengetahuan bagi pekerja untuk memenuhi dan mengembangkan serta meningkatkan keterampilan kerja agar mereka mampu, berguna, dan produktif. Hal tersebut terttera sebagai berikut : 'Vocational education as education designed to develop skill, abilities, understandings, attitudes,work habits, and appreciation needed by work to enter and make progress in employement on useful and productive basis' (Thompson,1973). Secara konsep pengertian dari AVA didukung oleh karakteristik yang pendidikan kejuruan yang dinyatakanWardiman Djoyonegoro. Menurut Djoyonegoro (1998) ada sembilan karakteristik pendidikan kejuruan, antara lain : (1) diarahkan untuk mempersi-apkan perserta didik memasuki dunia kerja; (2) didasarkan atas demand driven; (3) focus isi pendidikan ditekankan pada penuasaan pengetahuan, keterampilan, sikap, dan nilai yang dibutuhkan dunia kerja; (4) penilian kesuksesan peserta didik terdapat pada hands on (performa) dalam dunia kerja; (5) hubungan erat dengan dunia kerja adalah kunci sukse; (6) memiliki sifat responsive dan antisipatif terhadaap kemauan teknologi; (7) lebih menekankan pada learning by doing dan hands of experience; (8) memerlukan fasilitas mutahir untuk kegiatan prektik; serta (9)memerlukan biaya investasi dan operasional yang lebih besar dibandingkan pendidikan umum lainnya. Dari pendapat yang ada dapat dikatakan bahwa pendidikan Kejuruan memang direncanakan untuk mempersiapkan lulusannya dalam memesuki dunia kerja, dimana mereka diharapkan mampu beradaptasi, mandiri dengan bekal kompetensi yang mereka miliki.

\section{Konsep kewirausahaan}

Kewirausahaan (entrepreneurship) adalah proses krreatif, inovatif, mampu memanfaat-kan peluang, berani mengambil risiko, dan mampu memasarkan sekolahnya. Para ahli sepakat bahwa yang dimaksud dengan kewirausahaan menyangkut tiga perilaku yaitu: kreatif, komitmen (motivasi tinggi dan penuh tanggung jawab), dan berani mengambil risiko dan kegagalan. Kewirausahaan adalah proses inovasi dan kreasi (Kuratko \& Hodgetts, 1989 ; Hisrich $\&$ Peters, 2002). Orang yang berwirausaha disebut wirausahawan (entrepreneur). Entrepreneur adalah inovator dan kreator (Kao, 1991). Entrepreneur ialah seorang inovator (Hisrich \& Peters, 2002). Wirausaha yang sukses harus memiliki tiga kompetensi yaitu pengetahuan, keterampilan, dan sifat kewirausahaan. Ketiga kompetensi tersebut saling berkaitan. Keterkaitan ketiga kompetensi tersebut digambarkan sebagai berikut (Suryadarma,2009). 


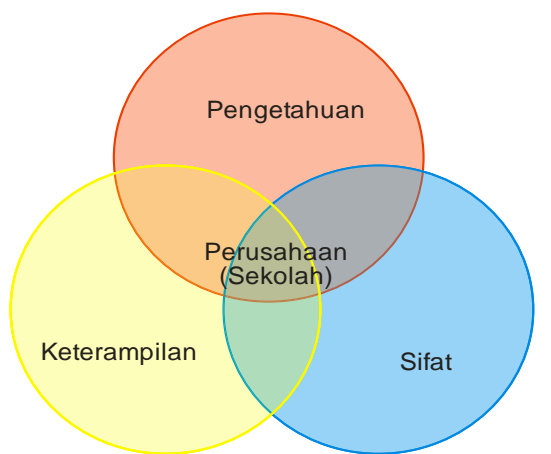

Gambar 1. Kompetensi (Anonim 4, 2005)

Kompetensi merupakan penguasaan pengetahuan, keterampilan, dan sifat. Pengetahuan adalah kumpulan informasi yang disimpan di otak dan dapat dipanggil jika dibutuhkan. Keterampilan adalah kemampuan menerapkan pengetahuan. Sifat adalah sekumpulan kualitas karakter yang memben-tuk kepribadian seseorang (Anonim 4, 2005). Seseorang yang tidak memiliki ketiga kompetensi tersebut akan gagal sebagai wirausaha yang sukses.

Keterampilan-keterampilan (skills) yang dibutuhkan oleh seorang wirausaha menurut Hisrich \& Peters (2002) adalah keterampilan teknikal, manajemen bisnis, dan jiwa kewirausahaan personal. Keterampilan teknikal meliputi: mampu menulis, berbicara, mendengar, memantau lingkungan, tek-nik bisnis, teknologi, mengorganisasi, membangun jaringan, gaya manaje-men, melatih, bekerja sama dalam kerja tim (teamwork). Manajemen bisnis meliputi: perencanaan bisnis dan menetapkan tujuan bisnis, pengambilan keputusan, hubungan manusiawi, pemasaran, keuangan, pembukuan, ma-najemen, negosiasi, dan mengelola perubahan. Jiwa wirausaha personal meliputi: disiplin (pengendalian diri), berani mengambil risiko diperhitungkan, inovatif, berorientasi perubahan, kerja keras, pemimpin visioner, dan mampu mengelola perubahan. Kewirausahaan menyangkut tiga perilaku utama kreatif, komitmen, dan berani mengambil risiko. Kewirausahaan adalah proses inovasi dan kreasi. Kewirausahaan dapat diartika sebagai singkatan dari: Kreatif, Enerjik, Wawasan luas, Inovatif, Rencana bisnis, Agresif, Ulet, Supel, Antusias, He-mat, Asa, Antusias, Negosiatif.(Suryadarma, 2009)

Program kewirausahaan di SMK pada dasarnya merupakan salah satu program pembelajaran yang bertujuan untuk penanaman nilai kewirausaha-an melalui pembiasaan, penanaman sikap, dan pemeliharaan perilaku wira-usaha. Kewirausahaan pada hakikatnya adalah sifat, ciri, dan watak seseo-rang yang memiliki kemauan dalam mewujudkan gagasan inovatif kedalam dunia nyata secara kreatif. Inti dari kewirausahaan adalah kemampuan untuk menciptakan sesuatu yang baru dan berbeda.(kreatif dan inovatif). Kreativitas adalah berpikir sesuatu yang baru; sedangkan inovasi adalah bertin-dak melakukan sesuatu yang baru. Secara etimologi kewirausahaan (entrepreneurship) pada hakikatnya merupakan suatu ke-mampuan dalam berpikir kreatif dan berperilaku inovatif yang dijadikan dasar,sumberdaya,tenaga penggerak, tujuan, siasat, dan kiat dalam menghadapi tantangan hidup (Suryana, 2003).

Wirausaha (entrepreneur) adalah seseorang yang mempunyai daya kreativitas dan daya inovasi yang kuat, memiliki kemampuan manajerial yg tinggi, menguasai pengetahuantentang bisnis secara mendalam danberperilaku dengan tujuan membentuk suatu usaha baru.Dengan menguasai jiwa entrepreneur diharapkan memiliki kombinasi motivasi, visi,optimisme,komunikasi,dan dorongan untuk memanfaatkan suatu peluang usaha. 
Tabel1.

\begin{tabular}{|c|c|}
\hline Nilai & Perilaku \\
\hline Komitmen & $\begin{array}{l}\text { Menyelesaikan tugas hingga } \\
\text { selesai }\end{array}$ \\
\hline $\begin{array}{l}\text { Risiko } \\
\text { moderat }\end{array}$ & $\begin{array}{l}\text { Tidak melakukan spekulasi } \\
\text { melainkan berdasarkan } \\
\text { perhitungan matang }\end{array}$ \\
\hline $\begin{array}{l}\text { Melihat } \\
\text { peluang }\end{array}$ & $\begin{array}{l}\text { Memanfaatkan peluang sebaik } \\
\text { mungkin }\end{array}$ \\
\hline Objektivitas & $\begin{array}{l}\text { Melakukan pengamatan secara } \\
\text { nyata untuk memperoleh } \\
\text { kejelasan }\end{array}$ \\
\hline $\begin{array}{l}\text { Umpan } \\
\text { balik }\end{array}$ & $\begin{array}{l}\text { Menganalisis data kinerja } \\
\text { waktu untuk memandu kegiatan }\end{array}$ \\
\hline Optimisme & $\begin{array}{l}\text { Menunjukkan kepercayaan diri } \\
\text { yg besar walau berada dalam } \\
\text { situasi besar }\end{array}$ \\
\hline Uang & $\begin{array}{l}\text { Melihat uang sebagai sumber } \\
\text { daya bukan tujuan akhir }\end{array}$ \\
\hline $\begin{array}{l}\text { Manajemen } \\
\text { proaktif }\end{array}$ & $\begin{array}{l}\text { Mengelola berdasarkan } \\
\text { perencanaan masa depan }\end{array}$ \\
\hline
\end{tabular}

\section{Kelas kewirausahaan di SMK}

Pendidikan kejuruan selalu didedikasikan untuk mempersiapkan lulusannya untuk bekerja di tempat kerja - biasanya dalam bisnis yang ada masyarakat. Siswa belajar keterampilan pekerjaan spesifik dan dipekerjakan atau diberikan kesempatan untuk menggunakan keterampilan ini sebagai pengalaman kerja melalui program yang menghubungkan mereka dengan bisnis. Pengalaman ini membantu siswa membentuk dasar pengetahuan tentang fungsi dan operasi bisnis dan mengembangkan beberapa tingkat keakraban dan kenyamanan dengan lingkungan bisnis - dua elemen dasar kewirausahaan. SMK telah menyadari bahwa memulai bisnis adalah hasil alami dari pelatihan keterampilan kejuruan (Ashmore et.al, 1990).. Penting bagi pendidik untuk mengenali kesempatan untuk kewirausahaan dan mencakup konsep tentang penciptaan usaha kecil di semua tingkat pendidikan. Agar pendidik menerima ide ini dan masuk ke kancah pendidikan kewirausahaan, Pusat Nasional untuk Penelitian di Amirika dalam mengembangkan Pendidikan Kejuruan Pendidikan seumur hidup Entrepreneurship Model (Gambar 14.1) untuk menjelaskan apa kewirausahaan berarti untuk audiens yang berbeda dalam berbagai tahap pembangunan pendidikan. Ini mengasumsikan bahwa semua orang di sistem pendidikan kita harus memiliki kesempatan untuk belajar pada tahap awal, tetapi tahap kemudian ditargetkan khusus untuk mereka yang benar-benar ingin memulai bisnis. Selanjutnya, adalah tepat untuk menangani aspek yang berbeda dari pendidikan kewirausahaan yang berkaitan dengan tujuan khusus masing-masing daerah pendidikan.

Berikut kemampuan dasar yang perlu ditanamkan pada kelas kewirausahaan (life long entrepreneurshif educational model )

\section{a) Dasar-dasar (tahap satu)}

Dalam kelas SD, SMP, dan SMA kami berharap bahwa orang-orang muda pengalaman belajar yang memungkinkan mereka untuk melihat kepemilikan usaha sebagai kesempatan nyata untuk semua orang. Pada tahap dasar. perlu belajar tentang ekonomi kita dan manfaat dari sistem perdagangan bebas. bisnis kecil merupakan unsur penting karena mewakili lebih dari 90 persen dari semua bisnis, menciptakan sebagian besar pekerjaan baru, dan dikreditkan dengan sebagian besar penemuan di negeri ini pemilih. Motivasi untuk belajar dan rasa peluang individu adalah hasil khusus di tingkat ini. Pengusaha datang dari segala macam latar belakang dan tingkat pendidikan.Untuk mempelajari siapa saja yang bisa berhasil jika ia memiliki keterampilan dan keberanian merupakan cara penting untuk memahami dunia ekonomi . 


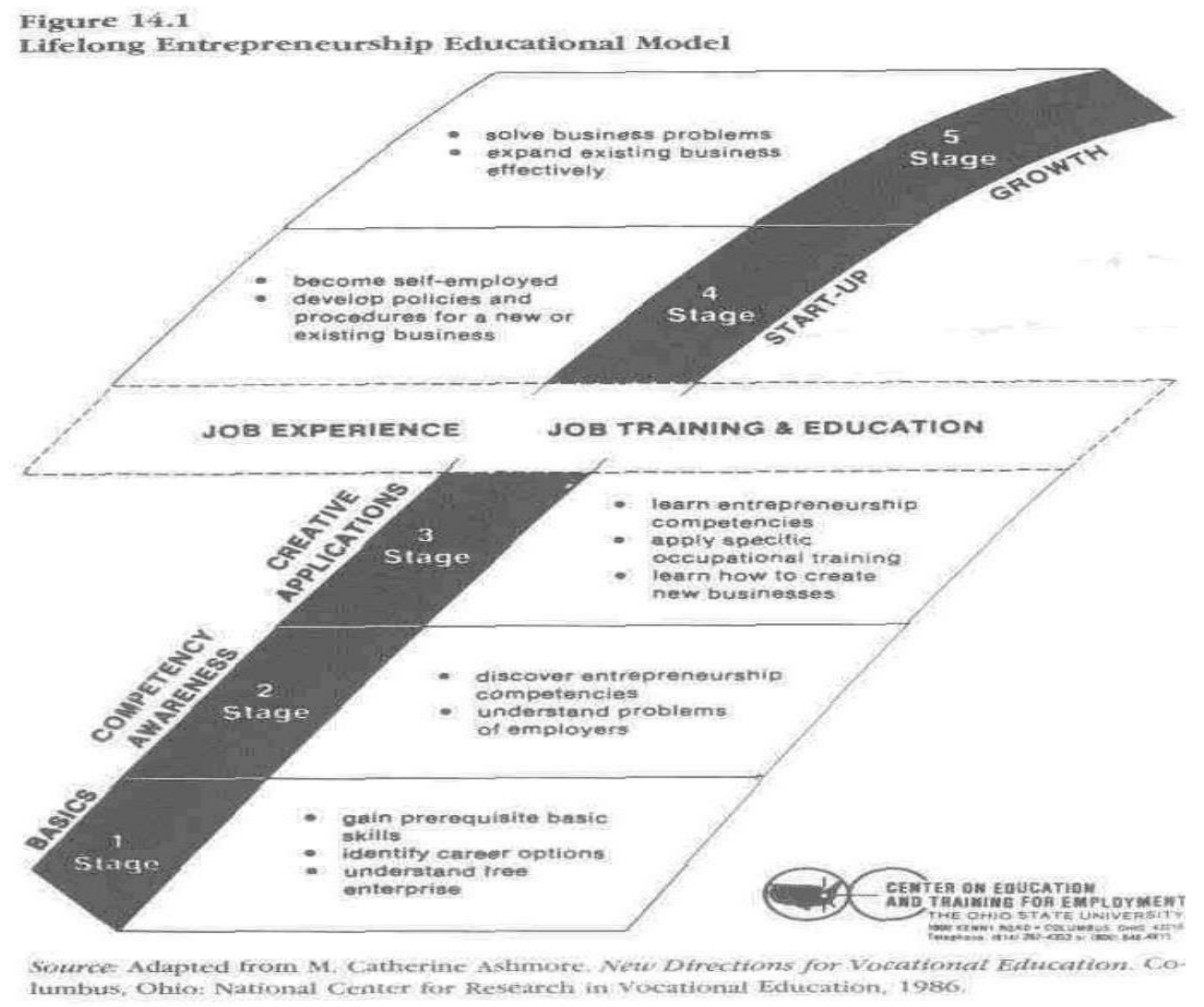

\section{Kompetensi kesadaran (tahap dua)}

Tahap ini mungkin mulai di mana saja dalam sistem pendidikan dimana kita bisa mengajarkan beberapa keterampilan kepemilikan bisnis melalui Kompetensi Kesadaran. Di kelas matematika kita dapat menggunakan proyeksi arus kas untuk mengajarkan penjumlahan dan pengurangan. Dalam kelas bahasa Inggris kita dapat menggunakan demonstrasi penjualan sebagai aktivitas komunikasi. Dalam penelitian sosial kita bisa fokus pada ekspor dan impor dengan berbagai negara link kami secara ekonomis. Akhirnya, dalam pendidikan kejuruan kita dapat belajar bagaimana memulai bisnis dengan menggunakan keterampilan teknis dari program kejuruan tertentu.

\section{b) Aplikasi kreatif}

Walaupun masih hanya merupakan pengalaman pendidikan, tingkat Aplikasi Kreatif membutuhkan lebih mendalam banyak dan luasnya pengetahuan dari salah satu tahap sebelumnya. Siswa akan mendapatkan kerangka kerja konseptual untuk semua tugas-tugas seorang pemilik usaha. Mereka akan belajar bagaimana menganalisis masyarakat bisnis dan masyarakat studi demografi untuk target strategi pemasaran mereka. Mereka akan belajar bahwa pasar melampaui sebuah komunitas tunggal dan mungkin termasuk negara-negara lain-karena mereka menganalisa peluang bisnis global.

Hasil utama pada tahap ini adalah kreativitas yang lebih besar, dalam mencari peluang bisnis dan pengalaman nyata, melalui rencana bersama untuk benar-benar memulai usaha sebelum siswa benar-benar siap menjadi pengusaha.

Kelas Kewirausahaan menawarkan pada siswa kesempatan tersebut dengan membantu 
mereka mengantisipasi dan menanggapi perubahan. Siswa belajar bahwa (1) walaupun pekerjaan mungkin berhasil dicapai saat ini dengan melakukan satu set tugas, besok yang berbeda yang sama sekali tugas (dan keterampilan) mungkin diperlukan, dan (2) karena bisnis selalu berubah, pekerja perlu menemukan cara-cara baru untuk melakukan pekerjaan yang diberikan atau cara-cara baru untuk melakukan pekerjaan yang diberikan lebih baik (Ashmore et al, 1989a). Ashmore brainstorming mempromosikan usaha potensial dalam berbagai bidang kejuruan sebagai sarana untuk membuat siswa sadar diri bahwa bekerja sebagai rute lain untuk kesuksesan dan harga diri pribadi. Agar efektif dalam mempersiapkan siswa untuk masyarakat yang berubah dan tempat kerja, pendidikan kejuruan harus melampaui penyampaian pengetahuan kerja, keterampilan kerja, dan pengalaman kerja. Ini harus menawarkan insentif siswa untuk berpikir kreatif tentang industri dan memperluas pemahaman mereka tentang peluang karir diberikan dalam industri itu.

Kemitraan yang biasanya ada di antara pemilik usaha masyarakat dan pendidik an kejuruan menawarkan manfaat lain untuk menanamkan pendidikan kewirausahaan dalam pendidikan kejuruan. konsep-konsep menciptakan bisnis.

Dalam penerapannya dilapangan kurikulum terletak pada guru, mungkin sulit bagi para guru yang memiliki pengalaman atau sedikit pelatihan untuk mengajarkan kewirausahaan. Lokakarya perlu untuk mendorong para gurui untuk refress dapat ditawarkan kepada semua guru kejuruan di suatu daerah sebagai bagian dari konferensi guru atau kelompok guru dalam disiplin yang sama (Ashmore et al, 1990) Karena dana untuk workshop memerlukan komitmen dari para pemimpin pendidikan di tingkat sekolah dan negara, pentingnya pendidikan kewirausahaan dalam konteks pendidikan kejuruan harus dikomunikasikan kepada administrator ini untuk mendapatkan dukungan mereka. (ERIC Clearinghouse on Karir Dewasa dan Pendidikan Kejuruan Columbus $\mathrm{OH}$, diambil tanggal 26 Oktober 2010)

\section{PENUTUP}

SMK merupakan bagian integral dari sector ekonomi yang ikut mendorong pertumbuhan ekonomi nasional, sehingga perlu dikembangkan kuantitas dan kualitasnya. Kualitas SMK akan mereflesikan kualitas tenga kerja Indonesia yang perlu dibangun untuk meningkatkan keunggulan kompetitif sumber daya manusia Indonesia.

Tantangan yang ada pada saat ini yang berhubungan dengan pendidikan antara lain meningkatkan kuantitas dan kualitas pendidikan kejuruan (vokasi) untuk memenuhi kebutuhan lokal dan nasional serta mampu bersaing secara global, serta menghasilkan SDM kreatif.Target menarik yang menjadi tujuan yaitu sekitar $70 \%$ lulusan SMK bekerja pada tahun Kelulusan dan seluruh SMK menyediakan layanan pembinaan pengembangan kewirausahaan.Paradigma ini memperlakukan, memfasilitasi, dan mendorong peserta didik menjadi subyek Pembelajar mandiri yang bertanggung jawab,kreatif, inovatif, sportif, dan berkewirausahaan Upaya untuk mencapai kualitas lulusan pendidikan kejuruan yang sesuai dengan tuntutan dunia kerja tersebut, perlu didasari dengan kurikulum yang di-rancang dan dikembangkan dengan 
prinsip kesesuaian dengan kebutuhan stakeholders.

Kelas kewirausahaan yang menerapkan pengintegrasian mata pelajaran kewi-rausahaan pada setiap muatan produktif .,pada kelas kewirausahaan ini diharapkan lebih efektif dal am penanaman jiwa wirausaha dan penanaman kemandirian para calon lulusan SMK Pariwisata Tata Boga sehingga para siswa nantinya lebih mandiri/professional dalam segala situasi berusaha.Perlu adanya kesiapan dari para guru dalam pelaksanaan kurikulum kelas kewirausahaan serta sarprasnya.

\section{DAFTAR PUSTAKA}

Alma, B. (2009). Kewirausahaan Untuk Mahasiswa Dan Umum. Bandung : Alfabeta.

American Institutes for Research in Behavioral Science." (1980). In Educational Training Components (ETC), Madison, Wis.: The Vocational Snidy Center.

Ashmore, M Catherine, and Geannina Guzman. (1988). Entrepreneurship Program Database. Columbus: The Ohio State University, National Center for Research in Vocational Education.

Direktorat Pembinaan Sekolah Menengah Kejuruan. (2005). Pokok-Pokok Pikiran Pengembangan Kurikulum Sekolah Menengah Kejuruan. Jakarta : Direktorat Jenderal Manajemen Pendidikan Dasar Dan Menengah,Departemen Pendidikan Nasional.
Djojonegoro, W. (1998). Pengembangan Sumber Daya Manusia Melalui Sekolah Menengah Kejuruan (SMK). Jakarta : Jayakarta Agung Offset.

Dollinger, MJ. (2003). Entrepreneurship Strategies And Resources. $3^{\text {rd }}$ Edition. NJ : Pearson Educational International.

Fischer, Lisa Mazzei, M. Catherine Ashmore, Terry W. Southwick, and Laurel A. Zlotnick. (1986), Risks and Rewards of Entrepreneurship. Columbus: The Ohio State University, National Center for Research in Vocational Education.

Kementerian Pendidikan Nasional. (2009).

Rencana Strategis Kementerian Pendidikan Nasional 2010-2014. Jakarta : Departemen Pendidikan Nasional.

Kuratko, DF., Hodgetts. (2004).

Entrepreneurship : Theory, Process, And Practice. $6^{\text {th }}$

Edition. Ohio : Thomson South Western

Suryana. (2003). Kewirausahaan : Pedoman

Praktis, Kiat, Dan Proses Menuju

Sukses. Edisi Revisi. Jakarta : Salemba

Empat.

Uno, HB. (2006). Orientasi Baru Dalam Psikologi Pembelajaran. Jakarta : Bumi Aksara.

Zimmerer TW.,Scarborough, NM. (2005). Essentials Of Entrepreneurship And Small Business Management. 4 Th Edition. NJ : Pearson Educational International 